\title{
Akarçay Havzası ve Van Gölü Havzası için 1901-2015 Yılları Arasında Standartlaştırılmış Yağış İndeksi'ne (SPI) Göre Trend Analizi
}

\author{
Mustafa KUZAY ${ }^{1}$, Mustafa TOMBUL ${ }^{2}$ \\ Geliş / Received: 11/11/2019 \\ Revize / Revised: 23/12/2019 \\ Kabul / Accepted: 08/01/2020
}

$\overline{\mathbf{O Z Z}}$

Bu çalışmada İklim Araştırma Birimi (Climatic Research Unit) tarafından oluşturulan yağı̧̧ dağıtım ızgaraları kullanılarak Akarçay Havzası ve Van Gölü Havzası'nda 12 aylık Standartlaştııılmış Yağış İndeksi değerleri belirlenmiştir. Böylece her izgarada belirlenen uzun dönemli kuraklık tespitinde kullanılabilen 12 aylık Standartlaştırılmış Yağış İndeksi değerleri sayesinde 1901-2015 yılları arasındaki dönem için Theil-Sen Eğim Tahmincisi Testi ile trend belirlenmiştir. 1901-2015 yılları arasındaki trend değerlerine göre Akarçay Havzası'nın kuzeyinde nemliliğin arttığı, güneyi ve doğusunda kuraklığın arttığı belirlenmiştir. Ayrıca Van Gölü Havzası'nın genelinde ise kuraklıklığın arttığı belirlenmiştir.

\section{Anahtar Kelimeler- Iklim Değişikliği, Kuraklık Analizi, Standartlaştırılmış Yağı̆ş Indeksi, Trend Analizi}

\footnotetext{
1Sorumlu yazar iletişim: mustafakuzay@eskisehir.edu.tr (https://orcid.org/0000-0002-6205-4819) Inş̧aat Mühendisliği Bölümü, Eskişehir Teknik Üniversitesi, ESTÜ Mühendislik Fakültesi İnşaat Müh. Bölümü 2İletişim: mtombul@eskisehir.edu.tr (https://orchid.org/0000-0002-6205-4819)

Inş̧aat Mühendisliği Bölümü, Eskişehir Teknik Üniversitesi, ESTÜ Mühendislik Fakültesi İnşaat Müh. Bölümü
} 


\title{
Trend Analysis for the Akarçay Basin and Van Gölü Basin According to Standardized Precipitation Index (SPI) Between 1901-2015
}

\begin{abstract}
In this study, 12 month Standardized Pericipitation Index values were determined in Akarçay Basin and Van Gölü Basin by using precipitation distribution grids created by Climatic Research Unit (CRU). Thus, the trend was determined with the Theil-Sen Slope Estimator Test for the period between 1901-2015 by means of the 12 month Standardized Pericipitation Index values that can be used in long-term drought detection in each grid. According to the trend values between 1901 and 2015, it was determined that humidity increased in the north of Akarçay Basin and drought increased in the south and east of Akarçay Basin. In addition, drought has increased in the Van Gölü Basin.
\end{abstract}




\section{GíRiş}

Kuraklık, belirli bölgedeki nem durumunun geçici dengesizliği sebebi ile su kıtlığıdır. Doğal bir iklim olayıdır. Herhangi bir zamanda veya mekanda görülebilir. İklimsel değişiklikler, tarımda ve insan hayatında su ihtiyacı ve buna bağlı olarak mahsul veriminde azalma gibi nedenlerden dolayı insan hayatı tehlikeye girebilir [1].

Doğal iklim değişikliği nedeni ile oluşan kuraklık üç ana başlık altında incelenebilir. Yağış azalması, yüksek sıcaklık, sızma, yer altı suyunda azalma, buharlaşma ve terlemede artma gibi sebeplerle Meteorolojik Kuraklık oluşur. Sonrasında aynı nedenlerle Tarımsal Kuraklık dönemi gerçekleşir. Tarımsal Kuraklık döneminde toprak neminde azalma, bitkilerde su sıkıntısı ve mahsul veriminde azalma görülür. Gerekli önlemler alınmadığı takdirde en tehlikeli ve uzun süreli kuraklık oluşturabilecek Hidrolojik Kuraklık dönemine geçilir. Bu dönemde ise akışta azalma, akarsu, göl vb. yerlerde kuruma ve azalma görülür. Bu durumlar sosyal, ekonomik ve çevresel zararlara sebep olur [2].

Kuraklık, tarım, ekonomi ve çevresel hasarın önemli bir nedenidir. Kuraklık etkileri yağış sıkıntısı ile uzun bir süre sonra ortaya çıktığından başlangıçlarını, kapsamını ve bitimini belirlemek çok zor olmaktadır. Bu nedenle, kuraklık dönemlerinin özelliklerini yoğunluk, büyüklük, süre ve mekânsal kapsam açısından objektif olarak ölçmek zordur. Dünya üzerinde yağış dağılımının kuraklık ile doğrudan etkisinin bulunduğu bilindiğginden analiz aşamasında kullanılacak verilerin netliği önemli bir konudur. Ayrıca bu verilerin yıllar içinde değişimi de göz önünde bulundurulması gerektiğinden hidrolojik incelemelerde en az 30 yıllık verisi olan yağış istasyonlarından faydalanılmalı veya uzun dönemli çalışmalarla ortaya çıkmış, kalibre ve valide edilmiş veri setleri kullanılmalıdır [3].

Bu çalışmada, 1901-2015 yılları arasında İklim Araştırma Birimi’nden (Climatic Research Unit) alınan dünya yağış verileri sayesinde belirlenen havzalarda Standartlaştırılmış Yağış İndeksi yöntemine göre Trend Analizi yapılmıştır. Ulaşılan sonuçlar Akarçay Havzası ve Van Gölü Havzası'nın kuraklık durumlarını belirtmektedir. Kuraklık durumlarına göre kapalı havzalarda su kaynakları yönetiminin sadece hidrolojik çalışmalar ile belirlenmesi ve belirlenen bu sonuçlara göre de gerekli kuraklık yönetim planlarının hazırlanması açısından çalışma oldukça önemlidir.Kuraklık analizinin Standartlaştırılmış Yağış İndeksi yöntemi ve trend analizi ile yapılmasındaki temel amaç 12 aylık periyotlarda su açığını hesaplayarak 1901-2015 yılları arasında kuraklık durumlarını belirlemek ve bu sonuçlar yardımı ile gerekli planların yapılmasına yardım edebilmektir.

\section{II. ÇALIŞMA ALANLARI}

Çalışma alanı olarak Akarçay Havzası ve Van Gölü Havzası'nın seçilmiş olmasının nedeni bu iki havzanın da kapalı havza olup, su kaynakları planlamalarının hidrolojik süreçlerle belirlenmesidir.

\section{A. Akarçay Havzası}

Akarçay Havzası İç Anadolu, Ege ve Akdeniz Bölgeleri arasında yer alan, sismik olarak aktif bir çöküntü havzasıdır. Havza topoğrafik özellikleri sebebi ile sularını denize boşaltma olanağına sahip değildir. Bu sebeple kapalı havza özelliğgi taşımaktadır. Havza alanı 7336,9 km² olup, Türkiye genel yüzölçümünün \%1'ini teşkil etmektedir [4].

Havza yüksekliği 952 metre ile 2610 metre arasındadır ve havza Emir Dağı Türkmen Dağı, Ilbudak Dağı, Sultan Dağı, Ahır Dağı ve Kumalar Dağı arasında kalmaktadır. Akarçay Nehri haricinde irili ufaklı bütün dereleri Eber ve Ekşehir Gölü'ne dökülmektedir. Akarçay Havzası gibi kapalı havzalarda toplam su miktarı hidrolojik çalışmalarla belirlenmektedir [4].

Akarçay Havzası 38.05-39.10 Kuzey Enlemleri, 30.00-31.85 Doğu Boylamları arasında yer almaktadır. Afyon, Çobanlar, Bolvadin, Eber, Akşehir, Çay, Şuhut ve Sincanlı alt havzalarından oluşmaktadır [5].

Havza suları, içme-sulama-tarım suyu ihtiyacı için depolanmaktadır. Akışa geçen sular ise havzanın yükseltisi az olan Eber ve Akşehir göllerine dökülmektedir. Günümüzde artan su tüketimine bağlı olarak göllere 
giden sularda azalma olmakta ve göl yüzeyleri küçülmektedir. Ayrıca son dönemlerde havzada görülen meteorolojik ve hidrolojik kuraklık sonucu ile göller kuruma tehlikesiyle karşı karşıya kalmışlardır. Şu anda da Eber ve Akşehir gölleri kuruma açısından ciddi risk altında bulunmaktadır [6].

Şekil 1'de görüldüğü gibi Akarçay Havzası'nda 12 adet akım gözlem istasyonu, 6 adet meteoroloji gözlem istasyonu ve 4 adet göl gözlem istasyonu bulunmaktadır [7].



Şekil 1. Akarçay Havzası'nda bulunan gözlem istasyonları

\section{B. Van Gölü Havzası}

Van Gölü Havzası, sularını Van Gölü'ne döken nehirlerin oluşturduğu kapalı bir havzadır. Dicle, Fırat, Hazar Denizi, Urmiye Gölü havzaları ile çevrilidir. Havza alanı 17976,43 km² dir. Havzanın yıllık su potansiyeli 3,54 milyar $\mathrm{m}^{3}$ tür. Havza, batı ve kuzeyde Nemrut, Süphan, Tendürek püskürtme konilerinin üzerinde bulunduğu su bölümü çizgisiyle Fırat-Dicle ve Aras Havzaları'ndan ayrılmıştır. Doğuda İran sınırı havzayı kuşatır. Güney sınırı ise gölü çok yakından izleyen sınırlar ve daha doğuda Sülün, Mengene ve Mirömer Dağları'nın doruklarından geçmektedir. Bu çizginin güneyi Fırat-Dicle Havzası'nda kalmaktadır [8].

Havza yüksekliği 1645 metre ile 4055 metre arasında değişmektedir ve su kaynakları açısından oldukça zengindir. Van, Erçek, Nemrut, Nazik, Arin, Akgöl, başta olmak üzere 17 adet göl bulunur. 10 adet sulak alan yer alır. Van, Arin, Erçek ve Akgöl tuzlu-sodalı diğer alanlar tatlı suludur. Karasu, Bendimahi, Deliçay, Engil, Zilan, Güzeldere, Memedik ve Karmış Çayı gibi pek çok akarsu bulunur [8].

Havza genelinde karasal iklim etkilidir ve Van Gölü'nün nemlendirici özelliğinden dolayı göl kıyılarında karasal iklim yumuşar. Temmuz ve Ağustos'ta azalsa da her mevsim yağış görülür. Van merkezde 384 mm/yıl yağış düşer. Maksimum yağış Nisan, minimum yağış Ağustos ayında görülür [8]. 
Van Gölü Havzası 37.50-39.35 Kuzey Enlemleri ve 42.10-44.30 Doğu Boylamları arasında yer almaktadır. Şekil 2'de belirtildiği gibi havzada 9 adet akım gözlem istasyonu, 3 adet meteoroloji gözlem istasyonu ve 3 adet göl gözlem istasyonu bulunmaktadır [7].

Van Gölü Havzası'nda 17 adet doğal göl, 3 adet baraj gölü, 40 adet gölet ve çok sayıda akarsu bulunmaktadır. Havzadaki belli başlı bazı göller Van, Erçek, Arin, Nemrut, Aygır, Keşiş, Akgöl, Süte, Şor ve Süphan gölleridir. Önemli akarsular ise Karasu, Bendimahi, Deliçay, Zilan, Karmuç, Hoşap’tır [9].

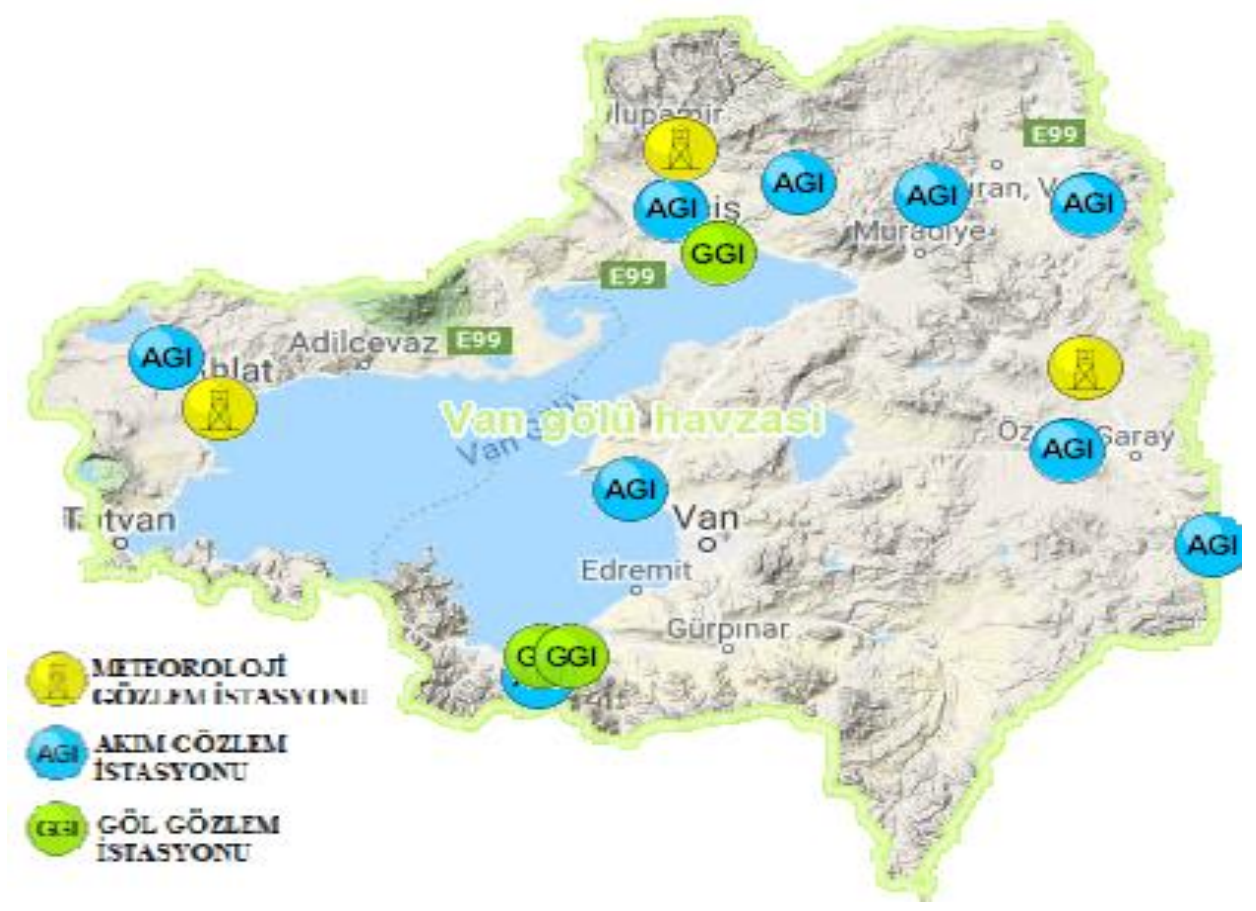

Şekil 2. Van Gölü Havzası'nda bulunan gözlem istasyonları

\section{YÖNTEM}

Kuraklık ile ilgili çalışma yapan araştırmacılar yağış verilerine ihtiyaç duydukları için, düzenli veriler alınabilinen yağış gözlem istasyonlarını veya tüm dünyada kabul edilen grid bazlı verileri kullanmaktadırlar. Gelişen bilgisayarlar sayesinde veriler matematiksel ve istatistiksel olarak daha kolay işlenmeye başlanmış, sonuç olarak ağır problemler ve analizler çözüme ulaşmıştır [3].

\section{A. Standartlaştırılmış Yă̆ış İndeksi}

Standartlaştırılmış Yağış İndeksi (SPI), belirlenen zaman dilimi içinde yağışın ortalamadan olan farkının standart sapmaya bölünmesi ile elde edilir. Yağıș İndeksi yöntemi yer altı suları, yüzey suları, rezervuar hazneleri ve toprak nemi gibi bütün su kaynakları ile ilgilenir. Farklı su kaynaklarının yönetimi ve izlenmesi belirli bir zaman ölçeğinde değerlendirilmesi Standartlaştırılmış Yağış İndeksi yönteminin ana mantığı olarak kabul edilebilir [10]. 


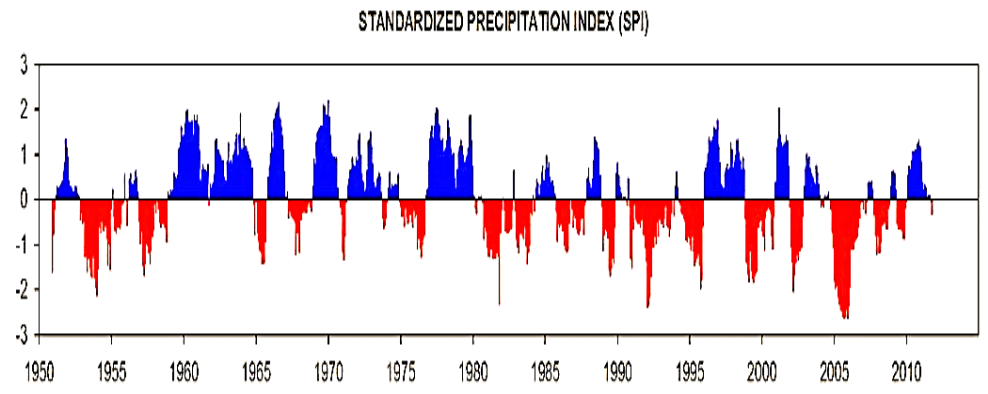

Şekil 3. 1950-2015 yılları arasında yapılan SPI analiz çalışması örneği

$$
S P I=\left(X_{i}-X\right) / \sigma
$$

Burada; SPI standartlaştırılmış yağış indeksi, $X_{i}$ aktüel yağış miktarı, $X$ ortalama yağış miktarı, $\sigma$ standart sapma değeridir[10].

Standartlaştırılmış Yağış İndeksi değerleri dikkate alınarak yapılan bir kuraklık değerlendirmesinde indeksin sürekli olarak negatif olduğu zaman periyodu kurak dönem olarak tanımlanır. İndeksin sıfırın altına ilk düştüğü dönem kuraklığın başlangıcı olarak kabul edilirken, indeksin pozitif değere yükseldiği ay kuraklığın bitimi olarak değerlendirilir [11].

6 aylık Standartlaştırılmış Yağış İndeksi, mevsimsel ve orta vadeli eğilimlerin yağışla ilgili olduğunu göstermektedir ve bu ölçekteki koşullara hala Palmer Kuraklık İndeksinden daha duyarlı olduğu düşünülmektedir. 6 aylık bir Standartlaştırılmış Yağış İndeksi, farklı mevsimlerdeki yağışları göstermede çok etkili olabilir. 6 aylık bir SPI'dan alınan bilgiler, bölgeye ve yılın zamanına bağlı olarak, anormal akış ve rezervuar seviyeleriyle de ilişkilendirilmeye başlayabilir. 12 aylıktan 24 aya kadar Standartlaştırılmış Yağış İndeksi, uzun vadeli yağış durumlarını belirtmektedir. Örneğin 12 aylık bir Standartlaştırılmış Yağış İndeksi, 12 ay ardışık görülen yağışların mevcut verilerinin önceki tüm yıllarda aynı 12 ay boyunca kaydedilenlerle karşılaştırılmasıdır. Bu zaman ölçekleri normalin üstünde veya altında olabilecek daha kısa periyotların kümülatif sonucu olduğu için daha uzun Standartlaştırılmış Yağış İndeksi değerleri, belirgin bir nemli veya kuru eğilim olmazsa, sıfıra doğru eğimlidirler. [12].

Standartlaştırılmış Yağış İndeksi yöntemine göre yapılan çalışmalarda; 1 aylık, 3 aylık, 6 aylık ve 12 aylık Standartlaştırılmış Yağış İndeksi değerleri ile Şanlıurfa istasyonundaki kuraklık dağılımları belirlenmiştir. Sonuç olarak, bu istasyonda 1986-2014 arasındaki aşırı kurak geçen ay sayısının, 1937-1985 yılları arasındaki kurak geçen ay sayısından daha fazla olduğu görülmüştür. Şanlıurfa istasyonu için; tüm zaman ölçeklerine göre en büyük Standartlaştırılmış Yağış İndeksi değerlerinin Ekim-Aralık 1972 dönemleri arasında meydana geldiği belirlenmiştir [13]. Antalya ili sınırları içerisinde bulunan sekiz meteoroloji istasyonuna ait 1970-2014 yılları arasındaki uzun süreli yağış verileri kullanılarak yapılan analizde uzun süreli yağış değerlerinin Standartlaştırılmış Yağış İndeksi yönteminin sınıflandırma değerlerine gore 3, 6, 12 ve 24 aylık dönemlerde incelendiğinde, Standartlaştırılmış Yağış İndeksi değerlerinde bir azalma olmadığı, Standartlaştırılmış Yağış İndeksi değerleri eğiliminin normale yakin kurak (0.99 -0.99) arasında yer aldığı hesaplanmıştır [14].

Tablo 1. Standartlaştırılmış Yağış İndeksi metoduna göre indeks değerleri ve sınıflandırma

SPI

İNDEKS DEĞERLERI
SINIFLANDIRMA 
e-ISSN: 2458-7575 (http://dergipark.gov.tr/bseufbd)

\begin{tabular}{cc}
\hline 2.0 ve fazla & Olağanüstü Nemli \\
1.50 ile 1.99 & Çok Nemli \\
1.00 ile 1.49 & Orta Nemli \\
-0.99 ile 0.99 & Normal Civarı \\
-1.00 ile -.1 .49 & Orta Kurak \\
-1.50 ile -1.99 & Çok Kurak \\
-2.0 ve düşük & Olağanüstü Kurak \\
\hline
\end{tabular}

\section{B. Theil-Sen Ĕ̆im Tahmncisi Testi}

Theil - Sen eğim tahmincisi bir dizi noktaya sağlam bir çizginin yerleştirilmesi için parametrik olmayan bir testtir. Test, örneklemdeki her bir çift nokta arasındaki çizginin eğimlerinin medyanını tanımlar ve trend belirlemede kullanılır [15][16]. Theil-Sen testi şu şekilde tahmin edilir:

$$
Q_{i}=\frac{y_{j}-y_{k}}{t_{i}-t_{k}} \quad i=1,2,3,4,5, \ldots \ldots \ldots
$$

Burada $y_{j}$ ve $y_{k}, t_{j}>t_{k}$ olduğu her zaman noktasında $t_{j}$ ve $t_{k}$ için geçerlidir ve yalnızca bir veri noktasının bulunduğu yerlerdeki gözlemlerdir [16].

$$
N=n(n-1) / 2
$$

$n$, zaman noktalarının sayısıdır. $Q_{i}$ eğimlerinin $\mathrm{N}$ değerlerini sıralamak için $\left(Q_{1} \leq Q_{2} \leq \ldots \leq Q_{N}\right)$ Sen tahmincisi $\left(\beta_{1}\right)$ kullanılır [16].

$$
\beta_{1}=\left\{\begin{array}{c|l}
Q_{[N+1) / 2} & \begin{array}{l}
N \text { tek ise } \\
\frac{1}{2}\left(Q_{N / 2}+Q_{(N+2) / 2}\right.
\end{array} \\
N \text { çift ise }
\end{array}\right\}
$$

$\mathrm{Bu}$ test sayesinde bir olayın veya veri setinin istenen periyotlarda trend analizi yapılabilir. Ayrıca bu testin Mann-Kendall, değiştirilmiş Mann-Kendall vb. trend testlerden farkı daha kolay olarak programlanabilir olmasıdır ancak mantıkları aynı olup Theil-Sen Eğim Tahmincisi Testi, Mann-Kendall Testi'nden belirli parametrelerle doğrulanmıştır [16].

\section{ANALİZ VE BULGULAR}

Akarçay Havzasında yükseklik değerleri 952-2610 metre arasında olup, Akarçay Havzası kapalı havza özelliği gösterir. Van Gölü Havzası yükseklik değerleri 1645-4055 metre arasında olup, Van Gölü Havzası da kapalı havza özelliği göstermektedir.

İncelenen havzaların belirlenen periyotlarda İklim Araştırma Birimi'nden (http://www.cru.uea.ac.uk/data) alınan yağış ızgaralarına göre belirlenen on iki aylık Standartlaştırılmış Yağış İndeksi (uzun dönemli kuraklık araştırması) değerlerine bağlı trend değerleri Theil-Sen yöntemine göre belirlenmiştir [3].

On iki aylık Standartlaştırılmış Yağış İndeksi olası gidiş trendini saptamak ve istatistiksel anlamda önemli bir artma yada azalma eğiliminin var olup olmadığını belirlemek amacı ile Akarçay Havzasında 5 
noktada, Van Gölü Havzasında 9 noktada 1901-2015 yılları arasındaki yağış değerlerinden elde edilen Standartlaştırılmış Yağış İndeksi verilerine Theil-Sen Testi uygulanmış ve \%95 istatistiksel anlamlılık seviyesinde trend sonuçları belirlenmiştir.

Şekil 4'de belirtildiği gibi Türkiye üzerinde Standartlaştırılmış Yağış İndeksi değerlerine göre çıkarılan trend değerleri 50*50 km²'lik alanları $\left(50 * 50 \mathrm{~km}^{2}\right.$ ’lik 1 zgaralar) tanımlandığından ve bu alanlar koordinat olarak belirlendiğinden Akarçay Havzası ve Van Gölü Havzası sınırları içine giren koordinatlar alınarak analiz yapılmıştır [3].

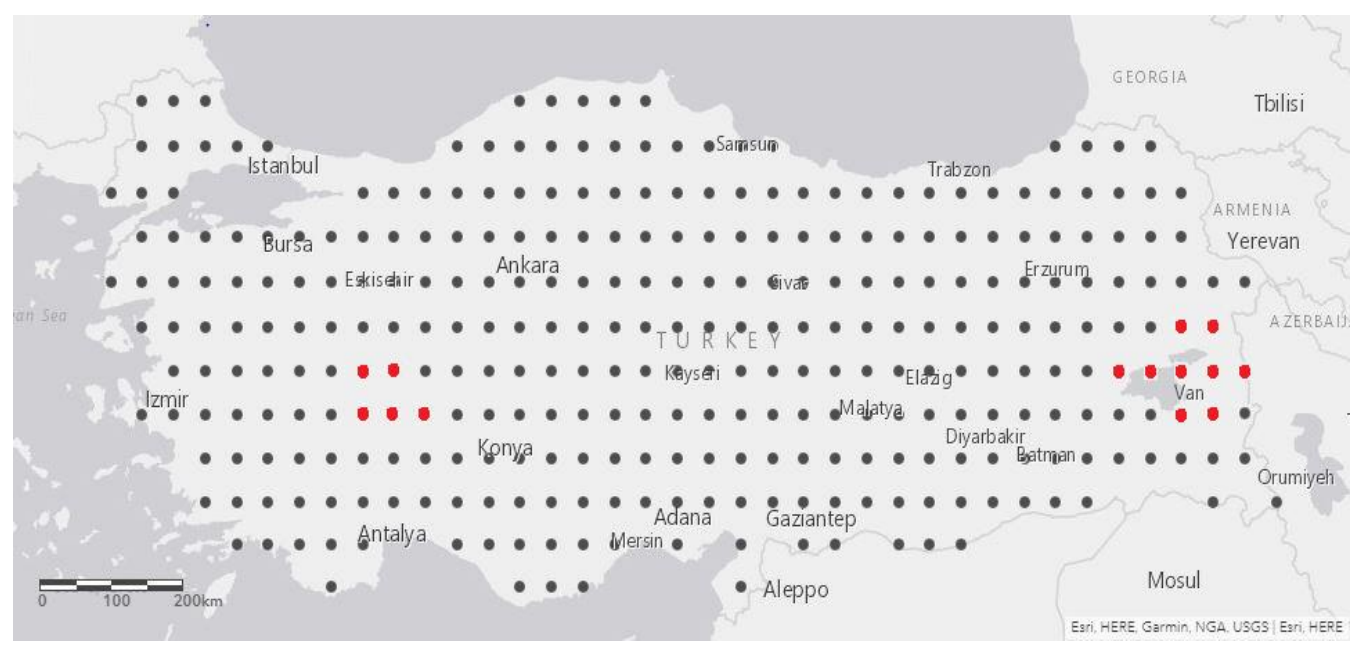

Şekil 4. İklim Araştırma Birimi (CRU) sayesinde elde edilen yağış verirlerinin alındığı 1zgara bazlı noktalar

Havzaların içerisinde yer alan noktalar belirlenmiş ve bunlar çıkarılmıştır. Değerler Akarçay Havzası için Tablo 2 ve Şekil 5, Van Gölü Havzası için Tablo 3 ve Şekil 6'da verilmiştir.

Tablo 2. Akarçay Havzası trend değerleri

\begin{tabular}{|c|c|c|}
\hline Noktanın Bulunduğu İ & $\begin{array}{c}\text { Noktanın Bulunduğu } \\
\text { Koordinat }\end{array}$ & Trend Değeri \\
\hline Afyon & 30.75 B 38.75 E & 0.1666701 \\
\hline Afyon & 31.25 B 38.75 E & 0.04478196 \\
\hline Afyon & 30.75 B 39.25 E & -0.1811211 \\
\hline Afyon & 31.25 B 39.25 E & -0.1262203 \\
\hline Konya & 31.75 B 39.25 E & -0.064324 \\
\hline
\end{tabular}




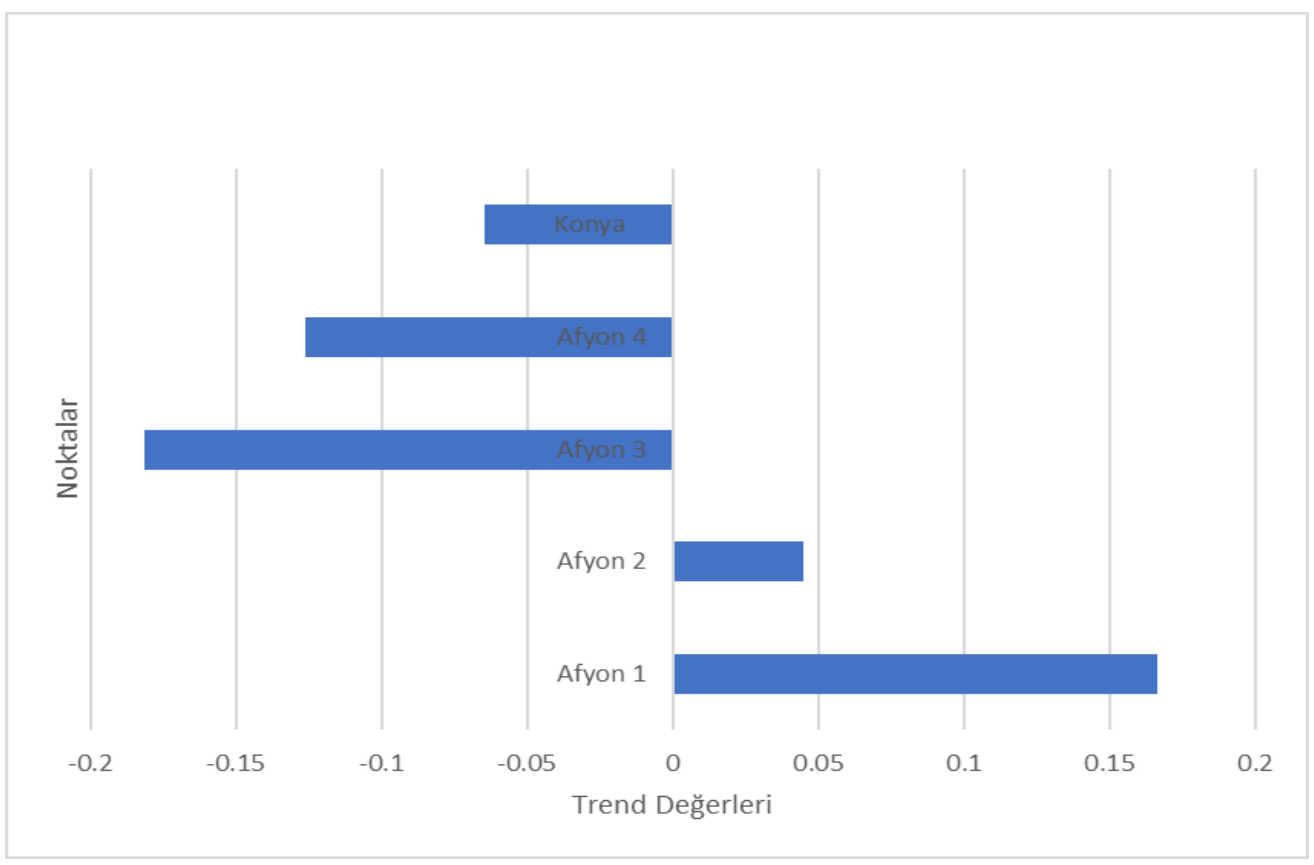

Şekil 5. Akarçay Havzası 1901-2015 yılları arası 12 aylık Standartlaştırılmış Yağış İndeksi trend değerleri

Tablo 3. Van Gölü Havzası trend değerleri

\begin{tabular}{|c|c|c|}
\hline Noktanın Bulunduğu İl & $\begin{array}{c}\text { Noktanın Bulunduğu } \\
\text { Koordinat }\end{array}$ & Trend Değeri \\
\hline Bitlis & 42.25 B 38.75 E & -0.2079928 \\
\hline Van & 43.25 B 39.25 E & -0.066058 \\
\hline Van & 43.25 B 39.75 E & 0.011199 \\
\hline Van & 42.75 B 38.75 E & -0.057588 \\
\hline Van & 43.25 B 38.75 E & -0.03988 \\
\hline Van & 43.75 B 38.75 E & -0.1804954 \\
\hline Van & 42.75 B 38.25 E & -0.090518 \\
\hline Van & 43.25 B 38.25 E & -0.1215154 \\
\hline Van & 43.75 B 38.25 E & -0.1999916 \\
\hline
\end{tabular}






Şekil 6. Van Gölü Havzası 1901-2015 yılları arası 12 aylık Standartlaştırılmış Yağış İndeksi trend değerleri

\section{SONUÇLAR}

Akarçay Havzası ve Van Gölü Havzası kapalı havzalardır ve yaklaşık aynı enlemde bulunmaktadırlar. Akarsuları Akarçay Havzası için Eber Gölü ve Akşehir Gölü’ne, Van Gölü Havzası için ise Van Gölü’ne dökülmektedir. Bu sebeple iki havza seçilmiş ve durumları karşılaştırılmıştır.

İklim Araştırma Birimi’nden (CRU) alınan ve açık kaynaklı erişime sahip olan 1901-2015 yılları arasındaki yağış ızgaraları ile oluşturulan veriler 12 Aylık Standartlaştırılmış Yağış İndeksi yöntemi ile kuraklık analizi yapılmış ve bu analiz çıktıları sonucu Theil-Sen Eğitim Tahmincisi Testi ile de trend durumu belirlenmiştir. 1901-2015 yılları arasındaki trend değerlerine göre sonuçlar maddeler halinde aşağıda sıralanmıştır. Bu sonuçlar Standartlaştırılmış Yağış İndeksi değerinin yağış açığına göre hesaplanmasından elde edilmiştir.

1. Akarçay Havzası'nın kuzeyinde nemliliğgin arttığı (0.1666701 0.04478196 aralığında) yani yağış verilerine bağlı Standartlaştırılmış Yağış İndeksi değerinin arttı̆̆ı, güneyi ve doğusunda (göllerin bulunduğu yerlerde) ise kuraklığın arttı̆̆ (-0.1811211 -0.1262203 aralığında) yani Standartlaştırılmış Yağış İndeksi değerinin azaldığı belirlenmiştir.

2. Van Gölü Havzası'nın ise neredeyse tamamında ise kuraklığın arttığı $(-0.2079928-0.03988$ aralığında) yani Standartlaştırılmış Yağış İndeksi değerinin azaldığı belirlenmiştir. Bölgede sadece Van 2 isimli noktada trend değerleri pozitif sonuç vermiştir.

Sonuçta ulaşılan bulgulara göre bu iki havza için kuraklık öncesi çalışmalar desteklenmelidir. Havza bazında gerekli içme-kullanma suyu durumları ve su kaynakları için gerekli planlama çalışmalarına önem verilmedilir.

\section{KAYNAKLAR}

[1] Özlü, H. (2007). Kuraklık Ve Su Yönetimi. İklim Değişimi ve Su Ekonomisi Paneli, 2007, Ankara: G. Ü. Bilim ve Teknoloji Stratejileri Araştırma ve Geliştirme Merkezi. 
[2] Köksoy, E. N. (2012). TR52 Bölgesi (Konya Karaman) Kurakllk İndeksi. http://planlama.mevka.org.tr, (05.03.2019).

[3] Kuzay, M. (2019). 1901-2015 Yılları Arasında Türkiye'de Standart Yağış İndeksi'ne (SPI) Göre Trend Analizi. Yüksek Lisans Tezi, Anadolu Üniversitesi, Fen Bilimleri Enstitüsü, Eskişehir.

[4] T.C. Orman ve Su İşleri Bakanlığı Su İşleri Genel Müdürlüğü (2016). İklim Değişikliğinin Su Kaynaklarına Etkisi Projesi Proje Nihai Raporu-Ek 13. http://iklim.ormansu.gov.tr/, (08.04.2019).

[5] T.C. Tarım ve Orman Bakanlığı Çölleşme ve Erozyonla Mücadele Genel Müdürlüğü. Akarçay Havzası. http://www.cem.gov.tr/erozyon/Files/moduller/havza/projeler/, (25.03.2019).

[6] Yılmaz, H., Tombul M. (2016). Akarçay havzası için entegre su kaynakları yönetiminin belirlenmesinde weap (water evaluation and planning system) modelinin uygulaması. Mühendislik Dergisi, 7(2), 271-277.

[7] T.C. Tarım ve Orman Bakanlığı. GeoData Uygulaması. http://geodata.ormansu.gov.tr/, (05.04.2019).

[8] T.C. Orman ve Su İşleri Bakanlığı Su İşleri Genel Müdürlüğü (2016). İklim Değişikliğinin Su Kaynaklarına Etkisi Projesi Proje Nihai Raporu-Ek 27. http://iklim.ormansu.gov.tr/, (08.04.2019).

[9] Elp, M., Şen, F., Çetinkaya, O. (2006). "Van Gölü Havzası Su Kaynaklarında Yaşayan Balık Populasyonlarının Karşılaştığı Problemler ve Çözüm Yolları. E. U. Su Ürünleri Dergisi, 23, 407-412.

[10] McKee, T. B., Doesken, N. J., Kleist, J. (1995). Drought Monitoring With Multiple Time Scales. American Meteorological Society Proceedings of 9th. Conference on Applied Climatology, 15-20 Ocak 1995, Dallas, 233-236.

[11] McKee, T. B., Doesken, N. J., Kleist, J. (1993). The Relationship Of Drought Frequency And Duration To Time Scales. American Meteorological Society 8th Conference on Applied Climatology, 17-22 Ocak 1993, Anaheim, California, 179-186.

[12] World Meteorological Organization (2012). Standardized Precipitation Index User Guide. https://library.wmo.int/index.php?lvl=notice_display\&id=13682\#.XcgWV1czbIU, (11.04.2019).

[13] Gümüş, V., Başak, A., Oruç, N. (2016). Standartlaştırılmış Yağış İndeksi (SYİ) Yöntemi ile Şanlıurfa İstasyonunun Kuraklık Analizi. Harran Üniversitesi Mühendislik Dergisi 01, 36-44.

[14] Dinç, N., Aydınşakir, K., Işık, M., Büyüktaş, D. (2016). Standartlaştırılmış yağış indeksi (SPI) yöntemi ile Antalya İli kuraklık analizi. Derim 33(2), 279-298.

[15] Theil, H. (1950). A rank-invariant method of linear and polynomial regression. I. Proc. Kon. Ned. Akad. v. Wetensch, (A53), 386-392.

[16] Sen, P. K. (1968). Estimates of the regression coefficient based on Kendall's. Journal of the American Statistical Association 63, 1379-1389. 